Digitalizacja archiwalnych numerów czasopisma naukowego Analecta Cracoviensia 1-24 (1969-1992) i ich publikacja w otwartym dostępie - zadanie finansowane w ramach umowy 672/P-DUN/2017 ze środków Ministra Nauki i Szkolnictwa Wyższego przeznaczonych na działalność upowszechniającą naukę

WENTZEL VAN HUYSSTEEN

KS. WEODZIMIERZ SKOCZNY

\title{
REALIZM NAUKOWY A TEOLOGIA
}

Niedawny list Ojca Świętego do uczestników zorganizowanego przez Watykan Sympozjum z okazji 300-lecia nauk przyrodniczych zawierał zachętę i zaproszenie zarazem do wspólnych poszukiwań intelektualnych naukowców, filozofów i teologów ${ }^{1}$. W poszukiwaniach tych między Scyllą całkowitej separacji i wzajemnej ignorancji a Charybdą redukowania jednej dyscypliny do drugiej, rozciąga się szerokie pole wzajemnych oddziaływań, które dla każdej ze stron mogą przynieść ubogacające rozszerzenie własnych perspektyw.

Szczególnie owocne na tej interdyscyplinarnej płaszczyźnie wydaje się być uwzględnienie filozofii nauki, która będąc genetycznie filozoficzną refleksją nad nauką przyrodniczą, ma wiele wspólnych pytań (choć niekoniecznie wspólnych odpowiedzi) odnoszących się do nauki najszerzej pojętej, a więc także teologii. Do tych wspólnych pytań należy np. problem racjonalności naukowych teorii. Toczące się wciąż dyskusje nad racjonalnością nauk przyrodniczych ukazały — ponad wszelkimi różnicami — jak złożoną strukturę ma każda teoria naukowa oraz jak niejednoznaczne bywają często wypowiedzi o racjonalnej metodzie. Pytanie o racjonalności w teologii jest chyba jeszcze bardziej złożone, a przecież zagadnienie to jest zagadnieniem kluczowym, gdyż od rozważenia kwestii epistemologicznego statusu teologii zależy wiarygodność, jaką będziemy obdarzać chrześcijańską wiarę. Od tego, jak podejdziemy do tego problemu, zależeć będzie, czy chrześcijańska wiara będzie kuriozum domagającym się jedynie tolerancji, czy też okaże się istotnym wymiarem, który nie tylko pozwoli zbudować adekwatny model realności, ale i połączy tę pracę z naszym ostatecznym pragnieniem poszukiwania sensu życia.

Kwestia racjonalności jest zagadnieniem bardzo złożonym, stąd konieczność uwzględnienia wielu innych szczegółowych problemów filozofii nauki.

* Poniższy tekst jest przeredagowaną wersją wykładu wygłoszonego podczas sympozjum Z problematyki wspótczesnej filozofii religii, 17 XI 1988, w Papieskiej Akademii Teologicznej w Krakowie.

${ }^{1}$ Zob. Physics, Philosophy and Theology. A Common Quest for Understanding ed. R u s se 11 R. J., S toe ge r W. R., Coyne G. V., Cittá del Vaticano 1988, s. 1-14. List ten omawia powyżej ks. M. Heller w swoim artykule (s. 20 n.). 
Do takich należy zagadnienie realizmu. Stanowisko to oznacza najogólniej, że teoretyczne konstrukcje mają swe realne odpowiedniki w rzeczywistości. W filozofii nauk przyrodniczych kwestia relacji między modelami teoretycznymi a modelowaną obiektywną rzeczywistością przeszła długą ewolucję poczynając od naiwnego realizmu, poprzez instrumentalizm, relatywizm poznawczy zwolenników podejścia Kuhna, do krytycznego realizmu² ${ }^{2}$ Problematyka ta ma oczywiście znaczenie dla teologii rozumianej jako krytyczna refleksja nad tym co Objawione, która świadomie czerpie ze związku z transcendentnym Bogiem jako Realnością „niezależną od nas"3.

W dalszej części artykułu zajmiemy się kolejno krytycznym realizmem w nauce, w teologii i postaramy się ukazać kilka wciąż otwartych kwestii w prezentowanej problematyce.

\section{Realizm naukowy}

Stanowisko krytycznego realizmu w nauce ${ }^{4}$ było formułowane pod presją koncepcji paradygmatów i rewolucji naukowych Kuhna ${ }^{5}$. W Kuhnowskim ujęciu terminy teoretyczne wchodzące w skład praw i teorii fizycznych są jedynie wyrazem socjologicznych i psychologicznych uwarunkowań, wyrazem aktualnej „mody” panującej w środowisku naukowym. Mają więc charakter względny - paradygmatyczny właśnie. Dzielą los swego paradygmatu, tzn. przy kolejnej fazie rewolucyjnej zmiany i one ulegną zmianie ustępując miejsca nowym, niewspółmiernym terminom.

Wobec takiego stanowiska sformułowano tezę realizmu krytycznego, który broni realności pojęć teoretycznych ${ }^{6}$. Przesłanką wskazującą na istnienie odpowiedniości między terminem teoretycznym a światem realnym ma być suk-

${ }^{2}$ Przegląd stanowisk w tej sprawie można znaleźć w książce Iana G. B a r b o u r a: Mity, modele, paradygmaty, Kraków 1984, s. 48-53.

${ }^{3}$ Podobnie, jak w nauce, także w teologii możemy wyróżnić kilka stanowisk co do statusu terminów teoretycznych. „The status of theories (doctrines) and models in theology can be similarly classified: 'naive realism', as theological fundamentalism about received doctrines; 'positivism' as biblical literalism (reliance on biblical texts as empirical data and disregard for interpretative categories); 'instrumentalism', whereby religious myths and stories are either simple aids to the pursuit of policies of life by capturing the imagination and strengthening the mind, or are able to evoke mystical experiences; and 'critical realism', whereby theological concepts and models are partial and inadequate, but necessary and, indeed, the only ways of referring to the reality that is God" (A. $\mathrm{Pe}$ a c o cke, Intimations of Reality. Critical Realism in Science and Religion, Notre Dame-Chicago 1984 , s. 40).

${ }^{4}$ To samo stanowisko realistyczne określane bywa również jako „conjectural” lub „sceptical and qualified realism" w celu podkreślenia odrębności od naiwnego realizmu. Zob. A. P e a c ock e, Intimations..., s. 29.

${ }^{5}$ T. S. K u h n, The Structure of Scientific Revolutions, Chicago 1970.

6 ,The basic claim made by scientific realism... is that the long-term success of a scientific theory gives reason to believe that something like the entities and structure postulated in the theory actually exist" (E. McMullin, A Case for Scientific Realism, w: Essays on Scientific Realism, ed. Le pin J., Berkeley 1984, s. 26). Spotykamy też „mocne” wersje tezy realizmu krytycznego; zob. H. W. P u t n a m, Mathematics, Matter and Method, vol. 1, Cambridge 1975, s. 69. 
ces nauki, który bez założenia realności „zakrawałby na cud”7. Sam sukces rozumiany bywa różnie, wszyscy realiści zgadzają się jednak na uznanie jakiejś jego wersji. Stanowisko to wydaje się szczególnie dotyczyć takich obiektów, do których odnoszą się stwierdzenia naukowe, a których status ontyczny nie jest jednoznacznie określony, gdyż są one nieobserwowalne np. elektrony, geny, antymateria, fale grawitacyjne, czarne dziury, kwazary, itp. Używane więc dla ich oznaczenia terminy teoretyczne mogą spełniać jedynie rolę „użytecznych fikcji" pomocnych w organizacji doświadczenia, ale nic nie mówiących o realności swych desygnatów. Za realnością tych obiektów zdaje się przemawiać nie tylko sukces nauk przyrodniczych, ale i ciągłość struktur teoretycznych służących w historii nauki do ich wyjaśniania. Jak zauważa Ernan McMullin ${ }^{8}$, gdyby historia nauki nie stwierdzała tej ciągłości, nie mielibyśmy ani logicznej ani metafizycznej podstawy by przyjmować naukowy realizm.

Stanowisko realizmu naukowego niesie wiele zagadnień i problemów, które prowadzą do kontrowersji. Przecież nie każde pojęcie teoretyczne znajduje swój odpowiednik w rzeczywistości. Historia nauki pełna jest tych teoretycznych pojęć, o których dziś wiemy, że nie istnieją, a w przeszłości wiązano z nimi wielkie nadzieje. Wystarczy przypomnieć eter czy flogiston. Jawi się więc tu pytanie: co decyduje o tym, że danemu terminowi odpowiada, czy też nie odpowiada obiekt realny, albo inaczej: jak daleko można się posunąć w teoretyzowaniu?

Oczywiście ostateczną instancją w nauce zawsze jest eksperyment, ale i on - choćby przez sam fakt jego interpretacji i przyjęcie niejawnych założeń może prowadzić do błędnego stwierdzenia realności de facto nie istniejących obiektów. Zaufanie do kryterium „czystego doświadczenia” zostało już dawno zakwestionowane w filozofii nauki. Stąd McMullin ${ }^{9}$ formułuje pewne zasady, które pomagają określić, kiedy można terminy teoretyczne odnoszącej sukces teorii uważać za mające swe realne odpowiedniki. Są to:

a - teoria musi być uznawana w okresie dłuższego przedziału czasowego

b - eksplanacyjny sukces teorii daje pewne racje, chociaż nie ostateczne gwarancje, by jej wierzyć

c — możemy mówić jedynie, że teoretyczne struktury są podobne do struktur

${ }^{7}$ H. Pu tn a m, What is Realism? [w:] J. Le plin, Scientific Realism, Los Angeles 1984, s. 141.

${ }^{8}$ E. Mc Mullin, $A$ Case for..., s. 22. McMullin podaje kilka przykładów takiej ciągłości. Wiąże się ona nierozerwalnie z używaną metaforą, która poprzez swą otwartość i sugestywność może wskazać kierunek prowadzenia badań. Tak np. geologów od dłuższego czasu intrygowało podobieństwo linii brzegowej Afryki i Południowej Ameryki. W roku 1915 Alfred Wegener sformułował hipotezę, według której następowało przesunięcie kontynentów. Ten model budził jednak wiele zastrzeżeń, jak choćby kwestia przemieszczenia się kontynentów przez dno oceanu, które jest znacznie twardsze od samego kontynentu. W latach 1960-tych, dzięki nowym danym o dnie oceanu, H. Hess zmodyfikował pierwotny model. Przemieszczające się elementy to nie kontynenty, ale raczej szerokie platy, które unoszą zarówno kontynenty, jak i dna mórz.

${ }^{9}$ E. Mc Mullin, A Case..., s. 26. 
realnego świata. Podobieństwo to oddaje się przy pomocy analogii stosowanej w teoretycznych modelach i metaforach

d - prócz wypowiedzi o istnieniu odpowiedników terminów teoretycznych nie wprowadza się innych twierdzeń np. o jakichś uprzywilejowanych, specjalnych sposobach ich istnienia itp.

Podając te zasady warto zauważyć, że realizm krytyczny nie jest ukrytą formą aprobaty dla realności wszystkich bytów postulowanych przez daną długo akceptowaną teorię. Teoria, o której jest mowa powyżej, charakteryzuje się nie tylko tym, że wzrastająca subtelność specyfikacji wewnętrznej struktury była osiągana przez długi okres czasu, ale także tym, że teoretycznie postulowane byty funkcjonowały w sposób istotny w argumentacji, a nie tylko były intuicyjnym postulatem „głębiej położonej rzeczywistości”.

Poza tym sukces wyjaśniania, o którym jest tu mowa, jest strukturalnym typem wyjaśniania. Oznacza to, że w wielu dziedzinach nauk przyrodniczych następowało, w ciągu ostatnich kilku stuleci, postępujące odkrywanie struktury. Stwierdzenie to zakłada w sposób oczywisty, że można wnioskować o realnej strukturze, która obecnie jest poza naszym zasięgiem. W wyjaśnieniu strukturalnym jednym z najważniejszych kryteriów jest owocność (fertility). Oznacza ona nie tylko możliwość przedstawiania nowych predykcji, ale także zakłada spełnianie przez teorię funkcji heurystycznej objawiającą się sugerowaniem modyfikacji lub wyobrażeniowych rozszerzeń istniejących modeli.

\section{Krytyczny realizm $w$ teologii}

Przeniesienie analiz krytycznego realizmu z nauki na teologię jest zadaniem ryzykownym. Teologia jest bardzo swoistą dziedziną nauki w sensie szerszym i bardzo łatwo ją zniekształcić przez jakąkolwiek próbę upodobnienia lub nawet redukcji do nauk przyrodniczych. Stąd pojawiające się zastrzeżenia, że mówiąc o realizmie na płaszczyźnie teologii nie mamy wciąż do czynienia z uznaną teorią wyjaśnienia, ale raczej z bardzo obiecującą i sugestywną hipotezą. Tym niemniej uważa się, że naukowy realizm w formie krytycznego realizmu zawiera olbrzymie możliwości do wykorzystania go dla potwierdzenia wiarygodności i ważności twierdzeń teologicznych.

Podobnie jak w nauce, tak i w teologii stanowisko realistyczne wyraża się twierdzeniem, że niedostępne bezpośredniemu poznaniu obiekty opisywane $\mathrm{w}$ języku teologii rzeczywiście istnieją. Teoretyczne modele w teologii nie są ich wiernymi odbiciami, ale także nie są jedynie wezwaniem do ekspresji uznania i czci, w której pomijałoby się kwestię ich realnego istnienia. Dla krytycznego realisty analogiczna funkcja metafory pozwala wypowiadać takie właśnie zdania w nauce, które nie pretendują do dosłowności a zarazem posiadają fundamentalną doniosłość ontologiczną. 
Podejmując zagadnienie realizmu Peacocke ${ }^{10}$ ostrzega przed swoistą dyskryminacją, w której dziedzina realności będzie redukowana jedynie do fizykalnych obiektów. Nie widać dlaczego cząsteczki kwantowe miałyby być bardziej realne niż komórki bakterii, osoba ludzka, czy nawet fakty społeczne lub Bóg. Pojawiająca się czasem kwestia, czy nauki i teologia mówią o tej samej realności, uzyskuje tu ważne zróżnicowanie na rozmaite poziomy realności. Nauka wyjaśniając realność naturalnego świata nie ma dostępu do Boga, podobnie jak teologia ma za swój przedmiot realność różną od fizykalnych struktur mechaniki kwantowej ${ }^{11}$.

Uważamy, że jest jednak pewna wspólna płaszczyzna, na której zarówno nauka jak i teologia winny podzielić się swą wiedzą o różnych, ważnych obszarach realności. Jest to płaszczyzna metanaukowej refleksji. To właśnie na tym poziomie mówimy o teologii i o nauce jako o „realistycznych” stanowiskach, tzn. stanowiskach, które wypowiadają wiarygodne zdania o obszarach rzeczywistości leżących poza naszym bezpośrednim doświadczeniem.

Próbuje się we współczesnych analizach wskazać na różnice i podobieństwa między modelami w nauce i w teologii ${ }^{12}$. Wśród różnic, jedną z najważniejszych wydaje się być obecność w teologicznej refleksji egzystencjalnego odniesienia (commitment) do Boga ${ }^{13}$. Zadaniem krytycznego realizmu nigdy nie jest podanie „dowodu” na istnienie Boga, ale uznając ten fakt za podstawowy prowadzi się analizy zawsze w jego kontekście.

Wśród podobieństw ${ }^{14}$ podkreśla się przede wszystkim, że modele teoretyczne w teologii podobnie jak modele w nauce spełniają funkcję eksplanacyjną. Pojawiły się bowiem próby sprowadzenia ich roli jedynie do wywoływania emocjonalnych lub moralnych odpowiedzi. Spełnianie przez nie powyższych funkcji w niczym nie wyklucza, że modele te pełnią także wyjaśniające i pozna-

${ }^{10}$ Intimations..., s. 36.

${ }^{11}$ McMullin przedstawia tę sprawę bardzo zdecydowanie: „Science has no access to God in its explanation; theology has nothing to say about the specifics of natural world". (Realism in Theology and Science. A Response to Peacocke, w: „Religion and Intellectual Life” 2: 1985 z. 4 s. 40).

12 Zob. np. S. McFague, Metaphorical Theology. Models of God in Religious Language, London 1983; J. M. Sos ki ce, Metaphor and Religious Language, Oxford 1985.

${ }_{13}$ Właśnie ze względu na tę różnicę T. Fawcett wprowadza nazwę „obserwacyjny” dla modeli naukowych, a modele w teologii, dla ich egzystencjalnego odniesienia, nazywa "partycypacyjnymi"; zob. T. F a w c e t t, The Symbolic Language of Religion. London 1970, s. 82. Peacocke wśród różnic wymienia na pierwszym miejscu obecność w teologii szczególnego modelu, który pełni rolę podstawowej metafory (root-metaphor). Jest to model Boga jako Stwórcy, Zbawcy i Ofiarnika. Ma on do spełnienia szczególną rolę i jest na szczycie teologicznych modeli i metafor, wyjaśniających doświadczenie religijne. W nauce nie mamy takiego wyróżniającego się modelu; zob. Intimations... s. 43.

${ }^{14}$ Peacocke wymienia następujące podobieństwa modeli w nauce i w teologii: (a) analogiczny charakter modelu, (b) model jest 'kandydatem do realności', trzeba go traktować poważnie, ale nie literalnie, (c) modele nie tyle obrazują obiekty, ile ujmują procesy, relacje i struktury, (d) model jest formułowany w kontekście wspólnoty naukowej, co jest ważne dla socjologicznego odniesienia danego modelu; zob. Intimations... s. $41-42$. 
wcze funkcje ${ }^{15}$. Przeciwnie, właśnie dzięki nim mogą wywoływać emocje i domagać się moralnych odpowiedzi.

Jednym z najważniejszych zagadnień w problematyce realistycznej w teologii jest kwestia kryteriów, które pozwalają uznać dany model teoretyczny za bardziej adekwatny od innych. Wśród kryteriów tych na pierwszym miejscu wymienia się zależność danego modelu od klasycznego tekstu chrześcijaństwa, jakim jest Biblia. Stanowi ona ostateczną „drogę” do Bożej realności sama będąc tą realnością, która funkcjonuje epistemologicznie jako bardzo ekskluzywny akces do Rzeczywistości Boga. To dzięki temu kryterium mówiąc o relacji Boga do ludzi używamy modelowej relacji ojcostwa a nie macierzyństwa. Model Boga-Matki, mimo że pewnie zawierający bardzo interesujące analogie, nie jest modelem Biblii16.

\section{Wnioski krytyczne}

1. Powoływanie się na sukces naukowej teorii jako podstawę do wnioskowania o realizmie używanych tam terminów jest $\mathrm{z}$ logicznego punktu widzenia nieuprawnione. Rozumowanie to jest bowiem rozumowaniem redukcyjnym, w którym wniosek ma jedynie status hipotetyczny. Sukces eksplanacyjny można osiągnąć przecież także przy pomocy fałszywych teorii, co często miało miejsce w historii nauki.

2. Rozszerzenie tej przesłanki na całą naukę, a więc mówienie o sukcesie nauki jako takiej, również nie zmienia w niczym trudności w kwestii realności terminów teoretycznych, gdyż:

a - terminy te stanowią jedynie część tego, co uważamy za naukę i nie wiadomo, czy to one przyczyniają się do owego sukcesu, bez względu na to, jak go mamy rozumieć.

b - nawet pomijając powyższą trudność wciąż mamy tu rozumowanie redukcyjne, a więc jedynie hipotezę o realności terminów teoretycznych.

3. Samo pojęcie sukcesu jest niejednoznaczne. Bardzo często słowo to występuje w kontekście wyjaśniania, czyli rozumiane jest jako sukces eksplanacyj-

15 Janet Soskice, komentując wypowiedzi o użyteczności teologicznych modeli do ożywienia wiary i ufności, pyta: "Faith in what? Trust in what?" i stwierdza, że „typically Christians respond to the models of their religious tradition not because they take them to be elegant and compelling means of describing the human condition but because they believe them in some way to depict states and relations of a transcendent kind" (Metaphor and..., s. 176).

16 Pisząc swoje „wyznania”, Michael Novak nie zgadza się na tlumaczenie przyjęcia pojęcia Boga Ojca jedynie poprzez czynniki kulturowe, odwołując się do nierozerwalności naszych wypowiedzi od zawartego w Piśmie Swiętym Bożego Objawienia: „I find it difficult to be persuaded that the answer lies in God's adaptation to human cultural conditions. The God of Judaism and Christianity did not in other matters hesitate to scandalize and shock the cultural presuppositions of His people. If God could choose to create the world as He wished, surely He could have chosen to reveal Himself as He wished, to be revealed. God did not reveal Himself as She" (Confession of a Catholic, San Francisco 1983, s. 35). 
ny. Wydaje się jednak, że w omawianym tu kontekście chodzi o dalej jeszcze idący sukces. Można go zwać technologicznym, gdyż sprawia, że teoretyczne modele i używane w nich metaforyczne terminy nie tylko lepiej wyjaśniają, lecz także pozwalają na nowe predykcje zarówno doświadczalne jak i technologiczne ${ }^{17}$. Ten właśnie sukces zdaje się wskazywać, że analizom teoretycznym odpowiada jakaś obiektywna rzeczywistość ${ }^{18}$.

4. Z powyższych uwag wynika, że realizm naukowy winien być bardzo krytyczny także co do własnych założeń. Wydaje się, że wersja krytycznego realizmu proponowana powyżej przez McMullina spełnia te warunki, wprowadzając jednak w efekcie tak niejednoznaczne zwroty jak „znaczacy przedział czasu w którym uznajemy daną teorię” czy bliżej nie określone „podobieństwo struktur teoretycznych do struktur realnego świata"19.

5. Teologia nie może — z oczywistych przyczyn — wykazać się sukcesem technologicznym podobnym do nauk przyrodniczych. Przekonanie o realności jest w niej jednak znacznie silniejsze niż w naukach, bo oparte nie tylko na emocjonalnym przylgnięciu do Boga, lecz także na czymś więcej — na osobistym doświadczeniu wiary w Boga Żywego, z którego to doświadczenia pochodzi owo emocjonalne przylgnięcie.

6. Teoretyzowanie teologa o tym, co Objawione nosi na sobie znamię szczególnego braku adekwatności, który w takim stopniu nie pojawia się w naukach przyrodniczych. Dla fizyka (o ile rozumiemy to co robi) podanie parametrów wyjściowych i sformułowanie teoretycznego modelu w postaci ogólnych praw zachowania w zasadzie kończy postępowanie. Trudności wynikają np. w fizyce kwantowej z niemożliwości jednoznacznego podania parametrów czy konieczności uwzględnienia komplementarnych ze sobą teorii. Oczywiście można wtedy zmienić wyjściowy postulat podania parametrów i uwzględnić komplementarność teorii. Gdy jest to zrobione, zrobiono wszystko, co można było uczynić na poziomie opracowań teoretycznych. Teolog zawsze będzie w zdecydowanie innej sytuacji. Będzie ona podobna do postawy św. Augustyna, który z trwogą zabierał się do jakiegokolwiek mówienia o Bogu. To dlatego ostatnie wiersze De Trinitate kończy on „raczej modlitwą niż rozumowaniem” ${ }^{20}$, pisząc: „cokolwiek powiedziałem w tych księgach z Twego, niech uznają to i Twoi; jeśli

17 ,The best kinds of evidence for the reality of a postulated or inferred entity is that we can begin to measure it or otherwise understand its causal powers. The best evidence, in turn, that we have this kind of understanding is that we can set out, from scratch, to build machines that will work fairly reliably, taking advantage of this or that causal nexus. Hence engeneering, not theorizing, is the best proof of scientific realism about entities" (I. Hacking, Representing and Intervening, Cambridge 1983, s. 275).

18 W omawianym powyżej ujęciu McMullina to, co nazywamy obecnie „sukcesem technologicznym”, jest nierozłączną częścią ujmowanego przez niego wyjaśniania strukturalnego. Jedną z jego głównych cech jest dostarczanie wartościowych predykcji doświadczalnych.

19 „This qualifications: 'significant period', 'some reason', 'something like', sound very vague, of course, and vagueness is a chalenge to the philosopher. Can they not be made more precise? I am not sure that they can; efforts to strengthen the thesis of scientific realism have, as I have shown, left it open to easy refutation" (E. McMullin, A Case... s. 26).

20 Sw. A u gu st y n, O Trójcy Swiętej, Poznań 1963, s. 458. 
coś z mego, przebacz Ty i Twoi niech przebaczą"21. Tak więc mimo największych starań wynik jest zawsze daleki od przedstawianej Rzeczywistości.

7. Wśród kryteriów uznania jednych teorii za lepsze, bardziej adekwatne od innych, wymieniają realiści krytyczni uwzględnienie biblijnego przekazu, który jest wyłączną drogą do Bożej Realności. Z katolickiego punktu widzenia trzeba by dodać jeszcze Tradycję i Urząd Nauczycielski Kościoła. Całe zagadnienie zastępowalności jednych teorii przez inne, przybiera w teologii raczej formę rozwoju, ewolucji, niż literalnej zastępowalności.

8. W tym ostatnim punkcie chcielibyśmy przedstawić bardziej osobisty pogląd na sprawę realności. Oczywiście sądzimy, że rzeczywiście istnieją obiekty opisywane w fizyce jako elektrony czy w biologii jako geny itp. Wierzymy też, że metafora Boga jako Ojca, Stwórcy, Króla, Pasterza, Sędziego naprawdę mówi coś o Bogu. Argumentacja za tym sądem i za tą wiarą jest jednak wciąż hipotetyczna i nie pozbawiona nieracjonalizowalnego zawierzenia.

W podsumowaniu warto podkreślić, iż podczas gdy 50 lat temu przeciwstawiano jeszcze ostro poznanie przyrodnicze i teologiczne, dziś wprowadza się zamiast opozycji rozległe spectrum zróżnicowań dotyczących różnych typów i form poznania zarówno w teologii jak i w nauce. Te epistemologiczne zbieżności chronią przed niektórymi ze złudzeń pozytywizmu oraz stanowią ważne pozytywne następstwo interdyscyplinarnych studiów dotyczących statusu nauk przyrodniczych i teologii.

\section{SCIENTIFIC REALISM AND THEOLOGY}

\section{Sum mary}

In this article the epistemological credibility of the theological theory formation is exemined against the background of emerging recent scientific realism. A discussion of the necessity of theological interaction with philosophy of science leads to the difficult problem of reference or reality depication in theological theories, and to an analysis of the present discussion on scientific realism. In this analysis special attention is drawn to the fact that in all forms of realism ontological claims imply that something can be inferred about real structures that are at present out of our epistemological reach. Against this background the necessary and central role of metaphors and models in science is disussed and linked to the criterion of fertility regarding all scientific explanations. Eventually the complicated problem of the reliability and the epistemological status of theological knowledge is discussed within the context of critical realism in theology. Special attention is given to provisional criteria for realism in theology, and eventually to the two central problems for any form of realism in theology: (a) the role of religious or faith commitment in theological reflection; (b) the problem whether models, which are as indispensable in theology as they are in science, can also in a meaningful way be regarded as explanatory and thus as progressive and successful.

21 Tamże, s. 459. 